\title{
THE ROLE OF SEA SURFACE TEMPERATURE IN THE RAINFALL REGIME IN SUB-SAHARAN AFRICA
}

\author{
MOURA, Maurício do Nascimento - mauriciomoura90@gmail.com \\ Universidade Federal do Pará / UFPA
}

AIMOLA, Luis Lacerda - luisaimola@gmail.com

Gur Aryeh Institute for Research and Education

\begin{abstract}
This study sought to understand the role of the surface temperatures of the ocean and continent in the variability of rains in sub-Saharan Africa, contributing to the improvement of weather forecasting and prevention of extreme events in the region. Through perturbation experiments using a climate model of intermediate complexity, we seek to understand the roles of sea surface temperature (SST) of ocean basins around the sub-Saharan Africa and the surface temperature in Southern Africa, in defining the spatial distribution of Spatial distribution of rainfall in the region of action of Intertropical Convergence Zone (ITCZ) which assumes an approximate shape of an "inverted S" during the quarter December-January-February in this continent, due to connections with other systems of the same scale. By comparing the regional perturbation experiments of SST and the continental surface temperature with respect to the climatology we came to the conclusion that the SST in the Atlantic and Indian Oceans have major contribution in the formation of "inverted S" of precipitation than the continent's surface temperature. Comparing these two ocean basins, the Indian SST has predominant role in the climate variability in sub-Saharan Africa, modulating the position and intensity of the ITCZ and therefore the formation of their spatial distribution across the continent.
\end{abstract}

KEYWORDS: Precipitation, tropical rains, sub-Saharan Africa, climate variability.

\section{O PAPEL DA TEMPERATURA DA SUPERFÍCIE DO MAR NO REGIME DE CHUVAS NA ÁFRICA SUBSAARIANA}

RESUMO: Este estudo busca compreender o papel da temperatura superficial do oceano e do continente na variabilidade das chuvas na África subsaariana, contribuindo para a melhoria da previsão de clima e prevenção a eventos extremos nessa região. Através de experimentos de perturbações usando um modelo climático de complexidade intermediária, buscamos entender os papéis da temperatura da superfície do mar (TSM) das bacias oceânicas ao redor da África subsaariana e da temperatura de superfície no sul da África, na definição da distribuição espacial das chuvas na região de atuação da Zona de Convergência Intertropical (ZCIT) que assume uma forma aproximada de um "S invertido" durante o trimestre Dezembro-Janeiro-Fevereiro sobre esse continente, devido a conexões com outros sistemas de mesma escala. Através da comparação dos experimentos de perturbações regionais da TSM e da temperatura superficial continental com relação à climatologia chegamos à conclusão de que a TSM dos oceanos Atlântico e Índico tem maior contribuição na formação do " $S$ invertido" de precipitação do que a temperatura de superfície do continente. Comparando essas duas bacias oceânicas, a TSM do Índico tem papel predominante na variabilidade climática do continente africano subsaariano, modulando o posicionamento e a intensidade das chuvas e, portanto, a formação de sua distribuição espacial ao longo do continente.

PALAVRAS-CHAVE: Precipitação, chuvas tropicais, África subsaariana, variabilidade climática.

\section{INTRODUCTION}

The distribution of rainfall in the region of the Intertropical Convergence zone (ITCZ) has, in recent decades, been the subject of many climate studies (MARSHALL et al., 2014; SCHNEIDER et al., 2014). This is because the ITCZ 
determines the rainy regime of any region of the tropics, significantly influences the energy balance of the Earth due to the albedo of its clouds, influences the formation of cyclones and participates in the interhemispheric redistribution of energy (WALISER; GAUTIER, 1993; MARSHALL et al., 2014; SCHNEIDER et al., 2014).

The spatial patterns of precipitation in Africa are generally controlled by the seasonal migration of ITCZ north to south twice a year. The ITCZ therefore imposes a significant influence on the weather of rainfall patterns, wind and temperature on the continent, setting a annual bimodal rainfall across subSaharan Africa.

The ITCZ on the African continent has a very definite seasonality with six months of drought from May to October in the central and southern part of the continent and six months with rains from November to April, a period that defines the rainy season in this part of the continent (NICHOLSON, 2000). The quarter of December, January, February (DJF) is considered the period of maximum rainfall amount in the rainy season the south-central Africa, time of year when the ITCZ has an very peculiar average spatial configuration in the northwest-southeast direction forming approximately an 'inverted S "(Figure $1 \mathrm{~A}$ and Figure 2), with maximum amounts of rainfall in the southern part, between $150-300 \mathrm{~mm}$ in the monthly climatology, with its position further south in approximately $20^{\circ} \mathrm{S}$ (WASHINGTON; TODD, 1999). In this configuration the ITCZ mainly affects countries like the Republic of Congo and Tanzania, and even countries on the east coast of the continent as Mozambique and Madagascar that have large occurrences of storms and tropical cyclones during the rainy season. The opposite happens in the June, July, August (JJA) quarter, in the dry season, when are recorded the lowest rainfall values (Figure $1 \mathrm{~B}$ ).

a)

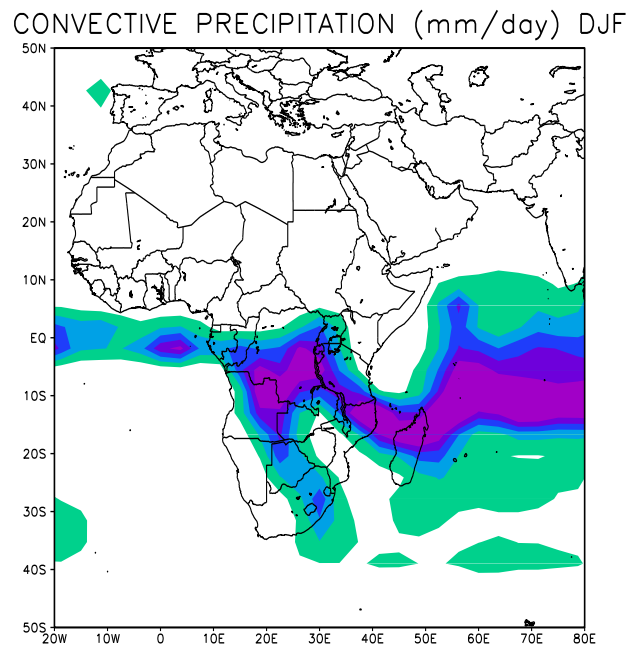

b)

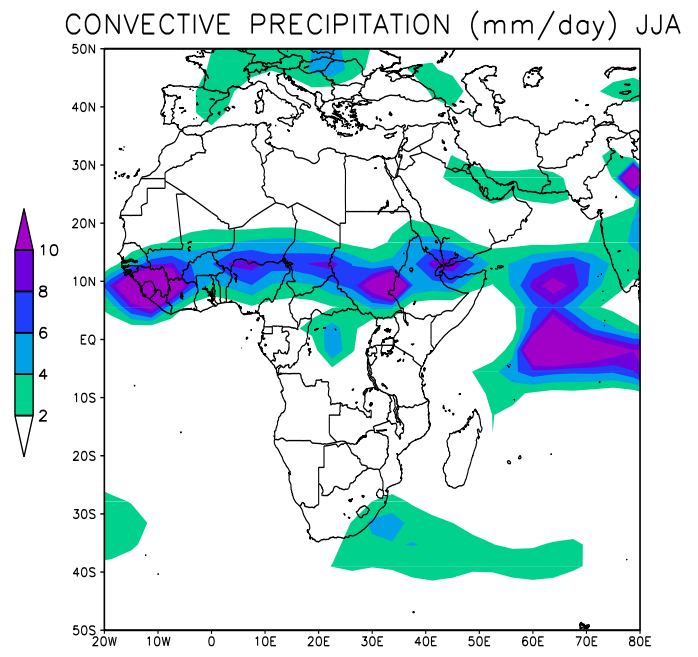

Figure 1 - Climatology of precipitation observed by ERA-Interim re-analysis data (19782007) on the African continent. a) Average climatological to DJF quarter, when the ITCZ gives a rough form of an "inverted S"; b) Average climatological for JJA quarter, when the ITCZ has a linear fashion almost parallel and north of the equator. 


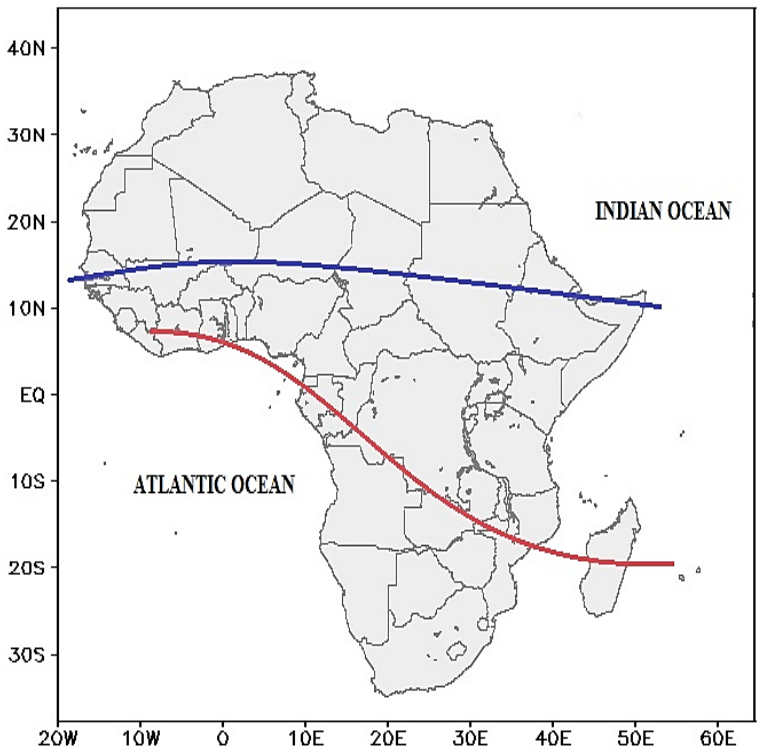

Figure 2 - Average location of the rainfall distribution on the African continent during the austral summer (red line) in an "inverted S" format, and in the boreal summer (blue line) when it is almost linear and above the equator.

In the last decades the east side of sub-Saharan Africa has suffered from of extreme climate events occurrences such as floods (WEBSTER et al., 1999; LAFIT et al., 1999) and severe droughts (HASTENRATH et al., 2007), which negatively impacted most sectors of the economy in that region very dependent on the availability of water resources. Against a backdrop of climate change, large amounts of rainfall and prolonged droughts can have serious economic, social and environmental consequences for different regions of Africa. Therefore, to increase the predictive ability and adaptation of the regions of this continent, it is necessary to understand the factors that determine the variability of the ITCZ in Africa, and its relation to the possible impacts of climate change on rainfall regimes in this continent.

The role of the oceans in climate variability of the African continent has been discussed by numerous studies in recent decades. Makarau and Jury (1997) found a relationship between the summer rains in southern Africa and the Indian Ocean SST. Other studies show that the Pacific Ocean also has contribution in the modulation of the rainy season in south-central Africa, however observed SST and precipitation data analysis have revealed that only $20 \%$ of the variability of rains in the quarter DJF on the East Africa region is directly attributed to the Pacific SST anomalies (LATIF et al., 1999; ROPELEWSKI; HALPERT, 1989). Other studies analyze the variability of the Atlantic SST and its relationship with the rains in Africa, as well as a mutual relationship with the Pacific SST and the Southern Oscillation (NICHOLSON; ENTEKHABI, 1986).

Several climate modeling studies searching to determine the causes of climate variability of precipitation in sub-Saharan Africa has been made. Cook (2000), for example, used global climate model to explore precipitation and surface temperature fields to study cloudiness patterns associated with largescale phenomena causing precipitation as the South Indian Convergence Zone 
(SICZ) and the Intertropical Convergence Zone (ITCZ). Other studies using global climate modeling to explain the occurrence of extreme events in the south-central Africa suggest that the variability of rainfall in Africa has strong relationships with the climate change process (FAUCHEREAU et al., 2003). However further modeling studies about the determinants of rainfall in subSaharan Africa are still very much needed because of the complexity of the mechanisms involved. This paper makes a contribution in the improvement of our knowledge on this important topic when using a model of intermediate complexity, which as will be described, confirms the main results so far found on the main causes of rainfall in this region.

The goal of this study was to identify the role of both, the SST in the adjacent oceans to sub-Saharan Africa, and the surface temperature of the southern part of that continent, in the formation of the average distribution of rainfall in the summer austral, here in this paper, called of "inverted S" (Figure 2 ). In Section 2 we present a description of the climate model used and the experiments to understand these relative roles in the formation of the ITCZ. In Section 3 we present the main results of the modeling experiments. In Section 4 , conclusions and final comments.

\section{MATERIAL AND METHODS}

\subsection{MODEL DESCRIPTION}

The perturbation experiments were conducted on the sea surface and the continent temperatures climatology using a climate model of intermediate complexity. The model was the Speedy (Simplified parametrization Primitive Equation-Dynamics), version 41 developed by Molteni et al. (2003).

The Speedy is a spectral hydrostatic model with horizontal truncation of T30 of 3,950, implying a spatial grid of 96 by 48 points in longitude and latitude, respectively. The model vertical resolution has eight layers in the atmosphere of $925 \mathrm{hPa}$ to $30 \mathrm{hPa}$. The model provides the possibility of coupling between the ocean mixture layer and the atmosphere through a Slab Ocean Mixed Layer module which calculates the SST through the heat flows between the atmosphere and the ocean surface and its distribution between cells of the slab ocean. The model parameterizations include schemes for the short and long wave radiation, convection, condensation on a large scale, momentum flows, heat and humidity, as well as vertical diffusion processes (MOLTENI et al., 2003).

Although the atmospheric model used in this paper is of intermediate complexity, previous studies show its good performance in reproducing the main features of the climate system in medium and large scale, both in the tropical latitudes as in extratropical regions (MOLTENI, 2003; BRACCO et al., 2004; KUCHARSKI et al., 2006).

\subsection{NUMERICAL EXPERIMENTS}

For all experiments we used as boundary condition the European Centre SST for Medium-Range Weather Forecasts (ECMWF) ERA-Interim re-analysis for a period of 30 years (1978-2007). We conducted experiments forcing the 
atmosphere with both, prescribed ocean surface temperatures (SST) without allowing heat fluxes in the ocean mixed layer, and with the Slab Ocean Mixed Layer model enabled to allow the heat flow to reach the equilibrium SST. As we found no significant differences between the two cases with regard to the distribution of rainfall and winds that could lead to different conclusions about our question, we describe below only the case of simulations with prescribed SST forcing.

Nine experiments were conducted, eight with disturbance in the monthly climatological surface temperature, both in the south central part of the African continent and adjacent oceans to the region, to detect the response of precipitation and wind to these disturbances without the coupling slab-oceanatmosphere. The first experiment, called CTRL, the undisturbed situation, is observed climatology, which was run for 30 years (January 1978 to December 2007) taking as input the monthly climatology of surface ocean temperature (SST). The other eight simulations were also run for the same period with anomalies in surface temperature in specific areas of Atlantic and Indian oceans and south-central part of Africa (Figure 3).

a)

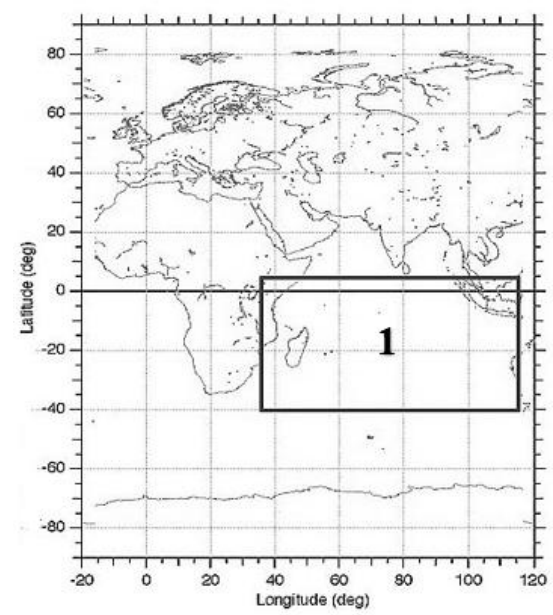

b)

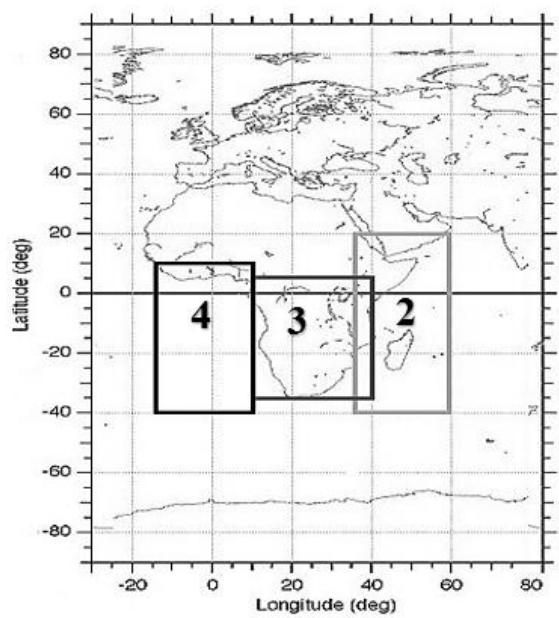

Figure 3 - Location of the areas which were made disturbances in the sea surface temperature and the continent. a) Box 1: Indian Ocean ( $5^{\circ} \mathrm{N}-40^{\circ} \mathrm{S}$ lat; $35^{\circ} \mathrm{E}-115^{\circ} \mathrm{E}$ long). b) box 2: Indian Ocean $\left(20^{\circ} \mathrm{N}-40^{\circ} \mathrm{S}\right.$ lat; $35^{\circ} \mathrm{E}-60^{\circ} \mathrm{E}$ long); Box 3: south-central Africa

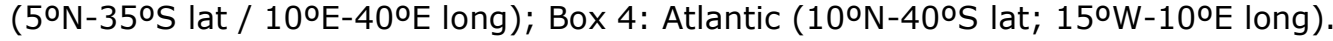

In the experiment called IND1 was cooled a strip $\left(35^{\circ} \mathrm{E}-115^{\circ} \mathrm{E} / 5^{\circ} \mathrm{S}-\right.$ $40^{\circ} \mathrm{S}$ ) in the Indian Ocean for every month compared to the climatological sea surface temperature (SST), as shown in Figure 3a (Box 1). The adopted disturbance was the August SST, considered the distribution of winter temperatures for the southern Indian region in the monthly climatology, with an average value (Box 1, Fig. 3a) of approximately $24^{\circ} \mathrm{C}$. For IND2 experiment the same strip in the Indian Ocean (box 1, Figure 3a) was heated by the same range, maintaining the January temperature for all months, considered the summer distribution of temperature in the monthly climatology, with a mean value of approximately $26^{\circ} \mathrm{C}$. Experiments were also carried out with cooling of $1.5^{\circ} \mathrm{C}$ (IND-) and heating of $1.5^{\circ} \mathrm{C}\left(+\right.$ IND) of an area (20N-40ㅇ $/ 35^{\circ} \mathrm{E}-$ 
$60^{\circ} \mathrm{E}$ ) in the Indian Ocean near the east coast of Africa, as shown in Figure $3 \mathrm{~b}$ (box 2). We chose the amplitudes, $+1.5^{\circ} \mathrm{C}$ and $-1,5^{\circ} \mathrm{C}$, to disturbances which are representative of both, the oscillations during ENSO events considered moderate, which produce thermal oscillations between $1^{\circ} \mathrm{C}$ to $2^{\circ} \mathrm{C}$ in the Pacific Ocean SST (DESER et al., 2009), and of as such temperature ranges interfere with global climate via atmospheric teleconnection (LIU; ALEXANDER, 2007). The Table 1 presents succinctly the experiments.

Table 1 - Set of experiments for both cooling and heating of the continent and the sea surfaces at $1.5^{\circ} \mathrm{C}$. Where IND: Indian Ocean; AFR: Africa; ATL: Atlantic Ocean.

\begin{tabular}{|c|c|c|}
\hline PERTURBATION & $\mathbf{- 1 . 5}^{\mathbf{}} \mathbf{C}$ & $\mathbf{+ 1 . 5}^{\mathbf{C}} \mathbf{C}$ \\
\hline IND- & $\mathrm{X}$ & - \\
\hline IND+ & - & $\mathrm{X}$ \\
\hline AFR- & $\mathrm{X}$ & - \\
\hline AFR+ & - & $\mathrm{X}$ \\
\hline ATL- & $\mathrm{X}$ & - \\
\hline ATL+ & - & $\mathrm{X}$ \\
\hline
\end{tabular}

In order to analyze the land-atmosphere interaction, AFR- and AFR+ experiments were carried out, where the surface temperature of a continental area, (Box 3: $10^{\circ} \mathrm{W}-40^{\circ} \mathrm{E} / 5^{\circ} \mathrm{N}-35^{\circ} \mathrm{S}$ ), was disturbed with both cooling and heating of $1.5^{\circ} \mathrm{C}$, respectively (Table 1 ). In the experiments $A T L-$ and ATL+, the SST in an Atlantic area, (box 4: $\mathrm{W}-15^{\circ}$ and $15^{\circ} / 40^{\circ} \mathrm{S}-10^{\circ} \mathrm{C}$ ), was perturbed with both cooling and heating of $1.5^{\circ} \mathrm{C}$ (Table 1 ). In all experiments performed the model was left reach the equilibrium after to run it for 30 years and we retained for analysis only the last 10 years of simulation to avoid any spurious effect, which was more than enough, since the model reached equilibrium well before.

\section{RESULTS AND DISCUSSION}

The Figure $4 a, b$ shows the calculation of the difference between the experiments IND1 and CTRL for the month of January, month when occurs the maximum amount of rainfall of the rainy season in south-central Africa, spatially setting on the average the "inverted S".

The positive anomalies of precipitation and wind are shown in the Indian Ocean between $10^{\circ} \mathrm{N}$ and the equator, and in isolated regions of the continent, but with no cloudiness in the eastern part. Thus, in the case of IND1 experiment, it is found that when we reduced the SST in this Indian Ocean range (Box 1), with an average range of $2^{\circ} \mathrm{C}$, the rainfall shows a slight increase, but restricted to the south-central part of the continent, in the region where is the "inverted S" under the influence of the ITCZ in austral summer. It is observed that the highest rainfall volumes are well evidenced in a nucleus in the central Indian Ocean, above $11 \mathrm{~mm}$, off the coast of Somalia. The atmospheric circulation pattern is changed in the disturbed area, with stronger 
winds and perpendicular to the coast, which lead moisture to the continent. These features were described by Todd and Washington (1999), which concluded that changes in SST at low latitudes, in the western Indian Ocean, induce the formation of anomalies in the movement of winds. These results also agree with those found by Nicholson (2000), Tyson and Preston-White (2000), which state that changes in circulation patterns have influence on the seasonal variation of rainfall associated with thermodynamic ocean conditions.

a)

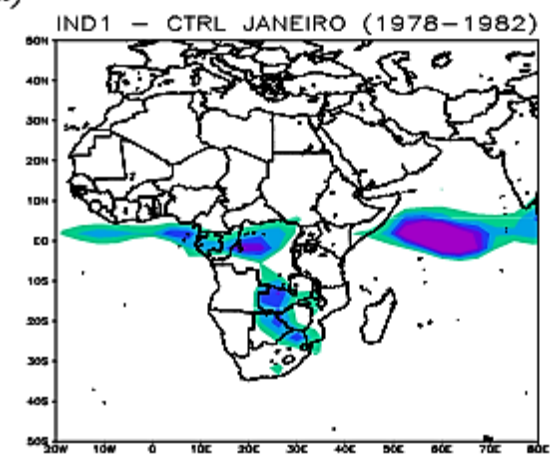

c)

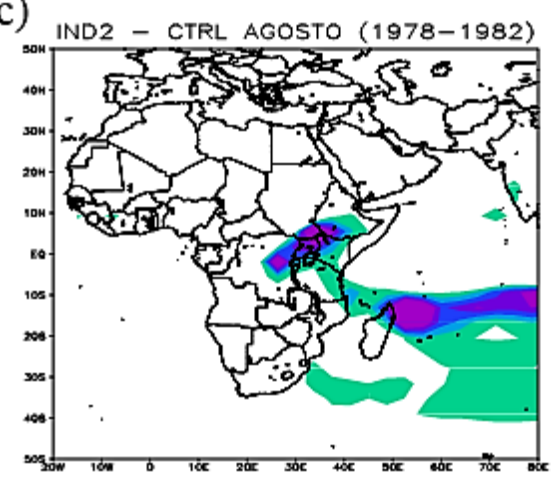

b)
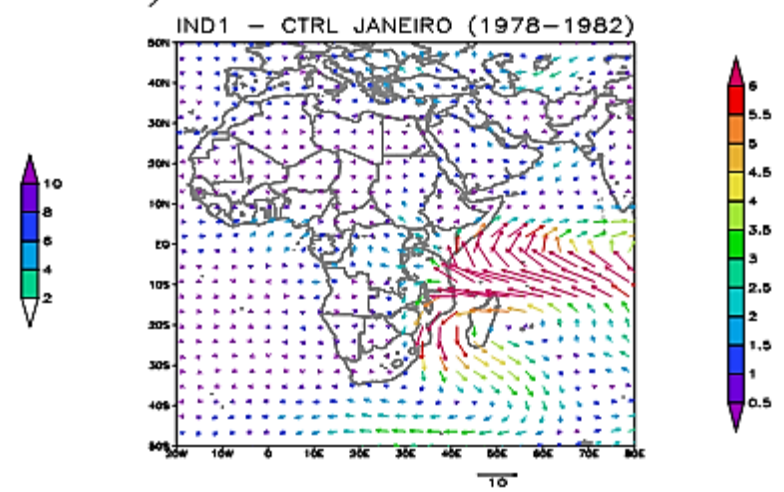

d)

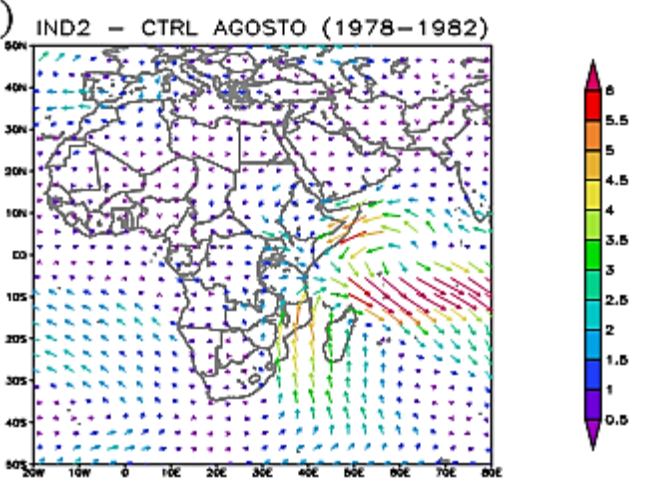

Figure 4 - Precipitation anomalies (mm/day) and wind $(\mathrm{m} / \mathrm{s})$ in the Indian Ocean (Box 1). $a, b$ : Difference between experiments IND1 and CTRL concerning the regional Indian Ocean cooling; c, d: Difference between IND2 experiments and related CTRL and regional warming of the Indian Ocean.

The Figure $4 \mathrm{c}$, d shows the calculation of the difference between the IND2 and CTRL experiments for the month of August when occurs, in the observed climatology, the minimum value of the volume of rainfall in southcentral Africa. According to the results of IND2 experiment, it appears that when we raise the Indian Ocean SST with an average amplitude of $2^{\circ} \mathrm{C}$, warming the surface waters, precipitation anomalies are generated, especially in the region where there was a disturbance, but with a few anomalies on the mainland, outside the region of the "inverted S". The wind circulation pattern near the surface is changed presenting an anti-cyclonic turning due to a high pressure system established in the working area, near Madagascar, causing no precipitation in the center of the system, and the presence of anomalies with intense rainfall above $11 \mathrm{~mm}$, in the system edges. 
Figure 5 shows the effects observed due to decreased and increased Indian Ocean SST near the east coast of Africa (box 2 - Figure 3b) with a fixed value of $1.5^{\circ} \mathrm{C}$ (Table 1 ). It was calculated from the difference between the experiments IND- and CTRL for precipitation and wind (Figure 5b), and between the experiments IND+ and CTRL (Figure $5 \mathrm{c}, \mathrm{d}$ ), both for the quarter December Janeiro-February (DJF), which is the rainy season in southern Africa where we find the average distribution in the shape of " $S$ " turns around the ITCZ. It can be seen from Figure $5 \mathrm{a}, \mathrm{b}$ that the cooling this area of the Indian Ocean, with $1.5^{\circ} \mathrm{C}$ of disturbance, causes precipitation anomalies in the continent, in the region where the "S" turns around, and east of the perturbed region, but with no precipitation within the cooling region. In Figure $5 c, d$, it is noted further increased precipitation anomalies, only in the heating area, with increased rainfall, above $11 \mathrm{~mm}$, coinciding with abnormalities in the circulation, in the same area disorder, with winds more intense in the basin of the Indian and perpendicular to the coast of Africa.
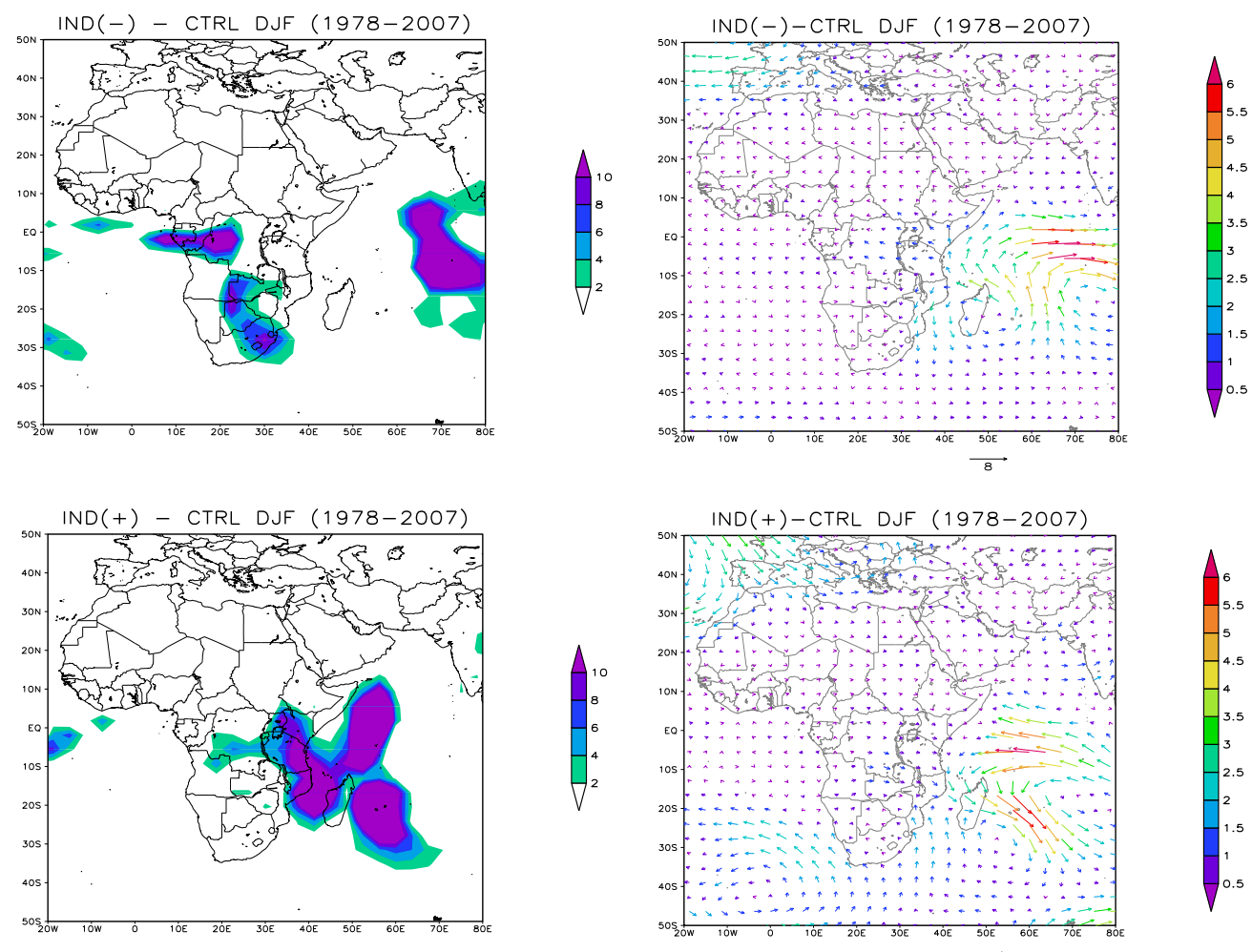

Figure 5 - Precipitation anomalies (mm/day) and wind $(\mathrm{m} / \mathrm{s}$ ) in the Indian Ocean (Box 2). a, b: Difference between IND- experiments and CTRL referring to the Indian Ocean cooling; $c$, d: Difference between experiments and IND+ and CTRL referring to the Indian Ocean warming.

The results of these four experiments show that both the heating, as the cooling of the areas of the Indian both close and distant from the east coast of Africa have obvious contribution to the formation of "inverted $S$ " in the ITCZ actuation period over southern Africa, mainly on the east coast of the continent, on the border west of the Indian Ocean. This is consistent with the results 
achieved by Latif et al. (1999) found that, through experiments with climate modeling that SST anomalies in the Indian Ocean directly influence climate variability in Africa, causing major flooding in the eastern region of the continent, as well as prolonged and severe droughts. This important role of the Indian Ocean has also been shown by several studies that have shown that the TSM Indian Ocean can play an important role in climate variability on the southcentral Africa, and that this applies particularly during DJF, according to various studies made with observational data (NICHOLSON; ENTEKHABI, 1986, 1987; NICHOLSON; KIM, 1997; NICHOLSON, 1997).

In view of these results, through simulations with cooling and warming of the Indian Ocean surface, it is evident the predominant role of the Indian Ocean in climate variability in Africa. These results also agree with Nicholson (2000) and Tyson and Preston-White (2000). But how important is this role? To answer this question, we conducted two sets of experiments perturbing the Atlantic and the African continent itself.

To analyze the possible role of land temperature on the earthatmosphere interaction and its impact on the circulation and precipitation, it was made two simulations with disturbances in the surface temperature of the continent (Box 3 - Figure 3b). The effects observed due to the heating and cooling of the surface of the African continent, both with ranges of $1.5^{\circ} \mathrm{C}$, are observed in Figure 6 by calculating the difference between the AFR- and CTRL and between the AFR+ CTRL experiments for DJF quarter.

It is observed that the cooling of the land surface at $1.5^{\circ} \mathrm{C}$ (Figure $6 \mathrm{a}, \mathrm{b}$ ) has little contribution to the formation of the "inverted $\mathrm{S}$ ", with little precipitation anomalies, between 2 and $4 \mathrm{~mm}$ in the southern part of Africa and that makes up the ITCZ, with more significant volumes of precipitation in the Indian Ocean. Thus, the cooling of the continent in order of $1.5^{\circ} \mathrm{C}$, held by AFRexperiment promotes few wind anomalies in surface and of precipitation, with a core set in the central region of the Indian Ocean, with over $11 \mathrm{~mm}$ volumes and lower volumes restricted to the central part of the continent.

A heating simulation was also performed $(A F R+)$ for the continent in $1.5^{\circ} \mathrm{C}$ for the quarter DJF. According to Figure $6 \mathrm{c}, \mathrm{d}$, it is observed that the continent heating also promotes little precipitation anomalies, with a few differences in the cooling simulation. We conclude that the variability of soil temperature in the south central region of Africa has no significant role in the positioning and intensity of the ITCZ. 

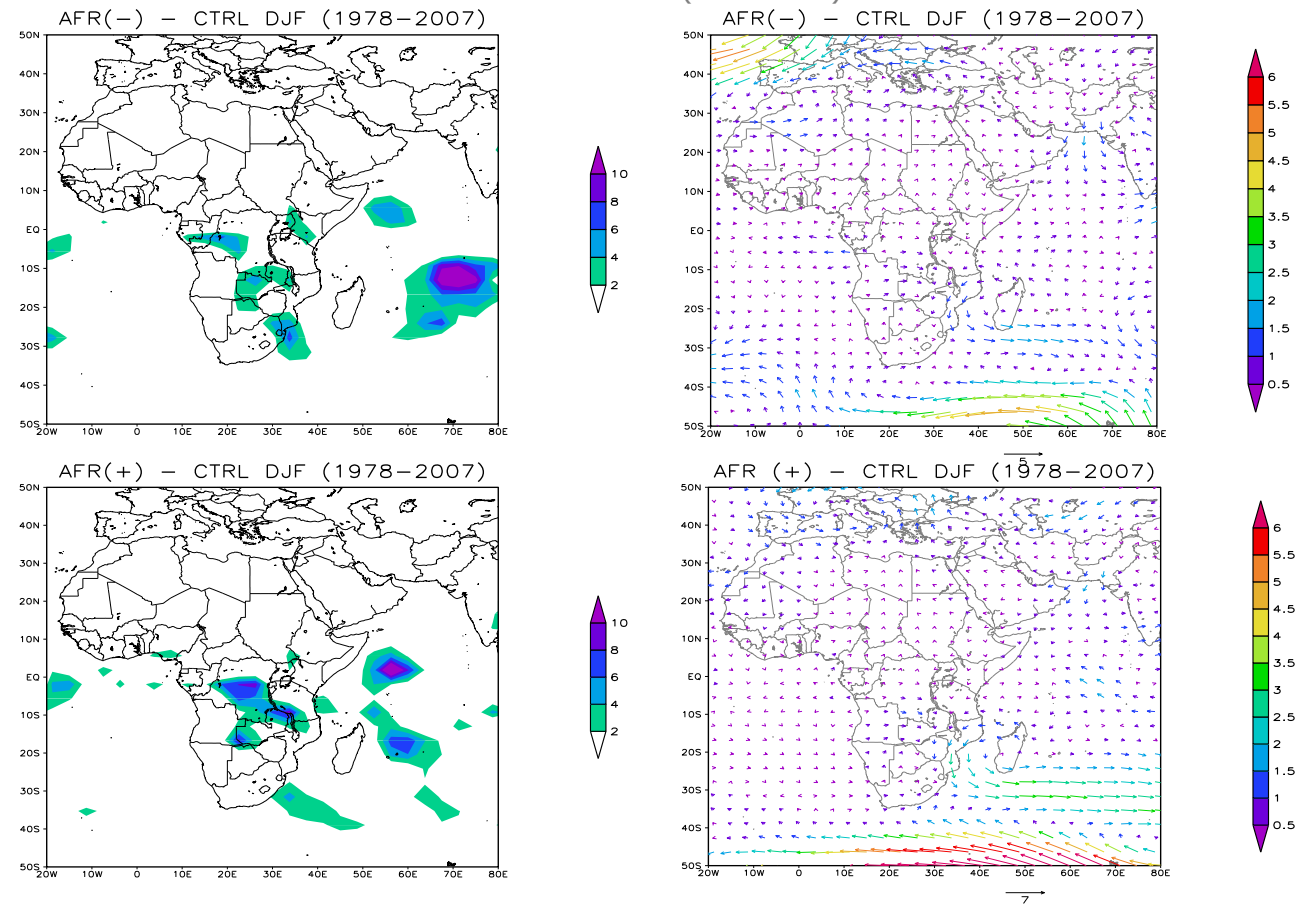

Figure 6 - Precipitation anomalies (mm/day) and wind ( $\mathrm{m} / \mathrm{s}$ ) in Africa (Box 3). AFRdifference between CTRL and experiments, and AFR+ and CTRL for the quarter DJF. $a, b$ : cooling the surface of the African continent; $c$, d: heating of the land surface.

To check what possible role the Atlantic Ocean has the in the positioning and intensity of the ITCZ in Africa, we conducted the ATL- and ATL+ experiments (Box 4 - Figure 3b). In the experiment ATL- (Box 4) was performed a cooling of $1.5^{\circ} \mathrm{C}$ in the Atlantic Ocean SST. Figure $7 a, b$ shows the effects of the Atlantic cooling, by calculating the difference between ATL- and CTRL experiments. According to Figure 7a, it is noted that the cooling in question causes little excess rainfall and volumes below $4 \mathrm{~mm}$. The wind circulation has few anomalies both in the ocean and on the continent, with the exception of a cyclonic whirl between Madagascar and the Mozambique Channel, but with small magnitude winds around between 0.4 and $2 \mathrm{~m} / \mathrm{s}$. 
a)

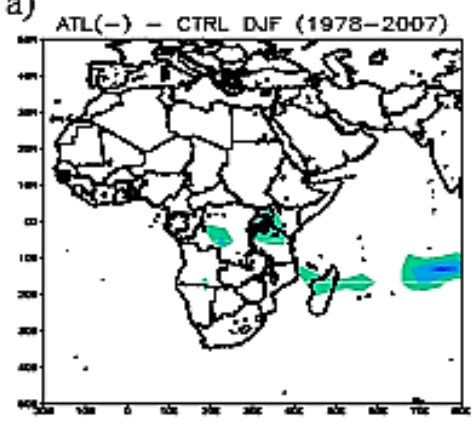

c)

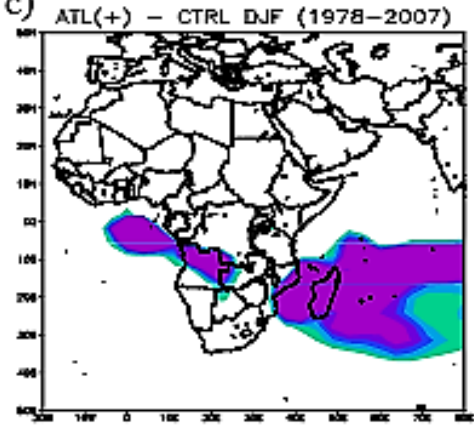

b)

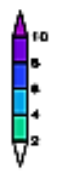

d)
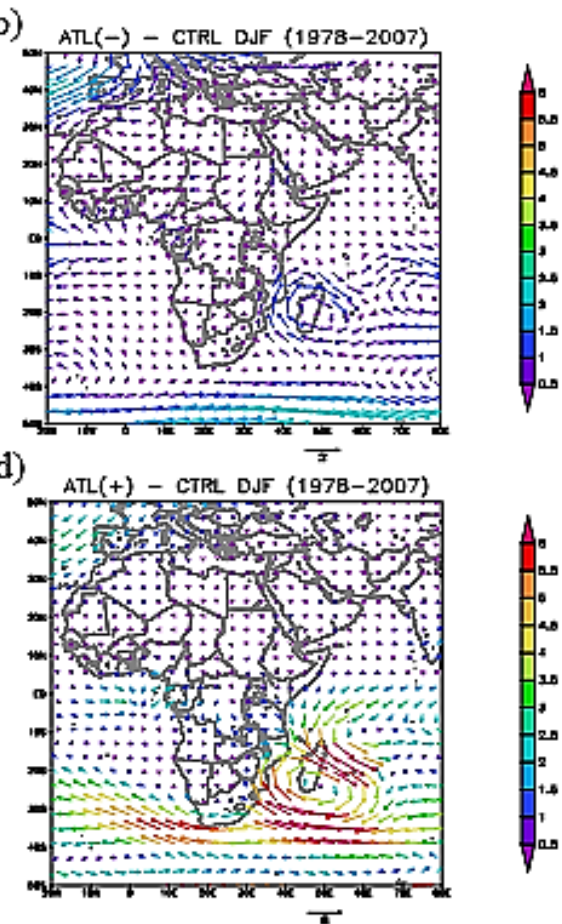

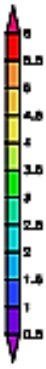

Figure 7 - Precipitation anomalies ( $\mathrm{mm} /$ day) and wind $(\mathrm{m} / \mathrm{s})$ in the Atlantic Ocean (Box 3). Difference between ATL- and CTRL and ATL+ CTRL experiments for the quarter DJF. $a, b$ : decrease in SST in the Atlantic Ocean; c,d: increase in SST in the Atlantic Ocean.

The opposite effect is seen in Figure 7c, where it is clear that the warming of the Atlantic Ocean generates large precipitation anomalies in the region of the "inverted $\mathrm{S}$ ", with over $11 \mathrm{~mm}$ rainfall volume in part of the continent, but mainly in western Indian Ocean, including Madagascar. The wind circulation near the surface (Figure 7d) shows a cyclonic whirl more intense with wind above $6 \mathrm{~m} / \mathrm{s}$, than the climatological average.

The experiments with modeling performed in this study make it evident that the disturbance of the ocean surface temperature directly influences the atmospheric circulation and consequently contribute significantly to the formation of cloudiness in the northwest-southeast direction that makes up the "inverted S" in the region of influence of the ITCZ and therefore in rainfall patterns of sub-Saharan Africa. Observational studies as Rocha and Simmonds (1997), Behera and Yamagata (2001) confirm this conclusion in stating that SST anomalies, positive or negative, act as driving forces and has its influence on the atmospheric circulation pattern in south-central Africa.

\section{CONCLUSIONS}

This research sought to determine, through perturbation experiments in an atmospheric model of intermediate complexity, the main factors governing the variability of rains in the Sub-Saharan Africa and hence determine the approximate distribution with a shape of an "inverted $S$ " of precipitation in the ZCIT region of activity during the quarter DJF, corresponding to the southern 
summer in this region. Specific factors such as SST and soil temperature were analyzed. Our conclusions are:

- The SST in the Atlantic and Indian Oceans have major contribution in the formation of "inverted $S$ " of precipitation than the surface conditions of South Africa;

- For the two oceans, the Indian West SST both on the coast of Africa, the South, between Africa and Australia, have predominant role in climate variability of the African continent, in relation to the Atlantic, since it modulates the positioning and the intensity of the rains and, therefore, the formation of its distribution along the continent with a format similar to an "inverted $S$ " of precipitation;

We consider that the orography in south-central Africa can be an important factor in the definition of the ITCZ position and intensity and should be analyzed in future studies to better understand the climate variability in in this region. Studies like Blumsack (1971) and Ogwang (2014) point out causes of this variability of rains, which go beyond the surface conditions of the oceans. For them, topographic influences can also cause local variations to this southern gradient of precipitation.

This article shows the great potential of intermediate complexity models for regional climate modeling compared to observational analysis and oceanatmosphere general circulation models and contributes to future modeling studies on the variability of the ITCZ in the context of global warming scenarios of anthropogenic origin. These scenarios imply an increase of SST average in ocean basins here studied and therefore in rainfall in sub-Saharan Africa. This will have important implications for adaptation strategies to changes in the hydrological cycle for the various countries in the region.

\section{ACKNOWLEDGEMENTS}

We thank to Vale Institute of Technology for providing the infrastructure and technical and academic support without which this work would not have been possible.

\section{BIBLIOGRAPHICAL REFERENCES}

BEHERA, S.K.; YAMAGATA, T. (2001). Subtropical SST dipole events in the southern Indian Ocean. Geophysical Research Letters, v.28, p.327-330.

BLUMSACK, S.L. (1971). On the effects of topography on Planetary Atmospheric Circulation. Journal of Atmospheric Sciences, v.28, p.1134-114.

BRACCO, A.; KUCHARSKY, F.; KALLUMMA, R.; MOLTENI, F. (2004). Internal variability, external forcing and climate trends in multi-decadal AGCM ensembles. Climate Dynamics, v.23, p.659-678.

COOK, K.H. (2000). The South Indian Convergence Zone and Interannual Rainfall Variability over southern Africa. Journal of Climate, v.13, p.3789-3804. 
DESER, C.; ALEXANDER, M.A.; XIE, S.; PHILIPS, A.S. (2010). Sea Surface Temperature Variability: Patterns and Mechanisms. Annual Review of Marine Science, v.2, p.115-137.

FAUCHEREAU, N.; TRZASKA, S.; ROUAULT, M.; RICHARD, Y. (2003). Rainfall Variability and Changes in Southern Africa during the 20th Century in the Global Warming Context. Natural Hazards, v.29, p.139-154.

HASTENRATH, S.; POLZIN, D.; MUTAI, C. (2007). Diagnosing the 2005 drought in equatorial East Africa. Journal of Climate, v.20, p.4628-4637.

KUCHARSKY, F.; MOLTENI, F.; BRACCO, A. (2006). Decadal interactions between the western tropical Pacific and the North Atlantic Oscillation. Climate Dynamics, v.26, p.79-91.

LATIF, M.; DOMMENGET, D.; DIMA, M.; GRÖTZNER, A. (1999). The role of Indian Ocean sea surface temperature in forcing east African rainfall anomalies during December-January 1998. Journal of Climate, v.12, p.3497-3504.

LIU, Z.; ALEXANDER, M.A. (2007). Atmospheric bridge, oceanic tunnel and global climatic teleconnections. Reviews of Geophysics, v.45, p.1-34.

MAKARAU, A.; JURY, M.R. (1997). Predictability of Zimbabwe summer rainfall. International Journal of Climatology, v.17, p.1421-1432.

MARSHALL, J.; DONOHOE, A.; FERREIRA, D.; McGEE, D. (2014). The ocean's role in setting the mean position of the Inter-tropical Convergence Zone. Climate Dynamics, v.42, p.1967-1979.

MOLTENI, F. (2003). Atmospheric simulations using a GCM with simplified physical parameterizations. I. Model climatology and variability in multi-decadal experiments. Climate Dynamics, v.20, p.175-191.

NICHOLSON, S.E. (1997a). An analysis of the ENSO signal in the tropical Atlantic and western Indian Oceans. International Journal of Climatology, v.17, p.345-375.

NICHOLSON, S.E. (2000). The nature of rainfall variability over Africa on time scales of decades to millenia. Global and Planetary Change, v.26, p.137-158.

NICHOLSON, S.E.; ENTEKHABI, D. (1986). The quasi-periodic behavior of rainfall variability in Africa and its relationship to the Southern Oscillations. Archiv für Meteorologie, Geophysik und Bioklimatologie, v.34, p.311-348.

NICHOLSON, S.E.; ENTEKHABI, D (1987). Rainfall variability in equatorial and southern Africa: relationships with sea surface temperatures along the southwestern coast of Africa. Journal of Applied Meteorology and Climatology, v.26, p.561-578.

NICHOLSON, S.E.; KIM, J.Y. (1997). The relationship of the El Nino Southern Oscillation to African rainfall. International Journal of Climatology, v.17, p.117135.

OGWANG, B.A.; CHEN, H.; LI, X.; GAO, C. (2014). The Influence of Topography on East African October to December Climate: Sensitivity Experiments with RegCM4. Advances in Meteorology, v.14, p.1-14. 
ROCHA, A.; SIMMONDS, I. (1997). Interannual Variability of South-Eastern African Summer Rainfall. Part I: Relationships with air-sea interaction processes. International Journal of Climatology, v.17, p.235-265.

ROPELEWSKI, C.F.; HALPERT, M.S. (1989). Precipitation patterns associated with the high index phase of the Southern Oscillation. Journal of Climate, v.2, p.268-284.

SCHNEIDER, T.; BISCHOFF, T.; HAUG, G. (2014). Migrations and dynamics of the intertropical convergence zone. Nature, v.513, p.45-53.

TYSON, P.D.; PRESTON-WHYTE, R.A. (2000). Weather and climate of Southern Africa. University Press, Oxford

TODD, M.; WASHINGTON, R. (1999). Circulation anomalies associated with tropical-temperate troughs in southern Africa and the South West Indian Ocean. Climate Dynamics, v.15, p.937-95.

WALISER, D.E; GAUTIER, C. (1993). A Global Climatology of the ITCZ. Journal of Climate, v.6, p.2162-2174.

WASHINGTON, R.; TODD, M. (1999). Tropical-temperate links in southern African and Southwest Indian Ocean satellite-derived daily rainfall. International Journal of Climatology, v.19, p.1601-1616.

WEBSTER, P.J.; MOORE, A.M.; LOSCHNIGG, J.P.; LEBEN, R.R. (1999) Coupled ocean-atmosphere dynamics in the Indian Ocean during 1997-1998. Nature, v.401, p.356-360. 